Joachim Frings · Christine Wondrak · Bernhard Schink

\title{
Fermentative degradation of triethanolamine by a homoacetogenic bacterium
}

Received: 22 December 1993 / Accepted: 24 February 1994

\begin{abstract}
With triethanolamine as sole source of energy and organic carbon, a strictly anaerobic, gram-positive, rod-shaped bacterium, strain LuTria 3, was isolated from sewage sludge and was assigned to the genus Acetobacterium on the basis of morphological and physiological properties. The $\mathrm{G}+\mathrm{C}$ content of the DNA was $34.9 \pm 1.0$ mol $\%$. The new isolate fermented triethanolamine to acetate and ammonia. In cell-free extracts, a triethanolaminedegrading enzyme activity was detected that formed acetaldehyde as reaction product. Triethanolamine cleavage was stimulated 30 -fold by added adenosylcobalamin (coenzyme $\mathrm{B}_{12}$ ) and inhibited by cyanocobalamin or hydroxocobalamin. Ethanolamine ammonia lyase, acetaldehyde:acceptor oxidoreductase, phosphate acetyltransferase, acetate kinase, and carbon monoxide dehydrogenase were measured in cell-free extracts of this strain. Our results establish that triethanolamine is degraded by a corrinoid-dependent shifting of the terminal hydroxyl group to the subterminal carbon atom, analogous to a diol dehydratase reaction, to form an unstable intermediate that releases acetaldehyde. No anaerobic degradation of triethylamine was observed in similar enrichment assays.
\end{abstract}

Key words Anaerobic degradation - Triethanolamine Homoacetogenic fermentation - Corrinoids

Triethanolamine degrading enzyme

Abbreviation NTA nitrilotriacetate

\section{Introduction}

Triethanolamine is a constituent of agricultural chemicals, aquatic herbicides (as copper-triethanolamine), household

J. Frings $\cdot$ C. Wondrak $\cdot$ B. Schink $(\varangle)$

Fakultät für Biologie, Universität Konstanz, Postfach 5560

D-78434 Konstanz, Germany

Tel. +49- (0)7531-882140; Fax +49- (0)7531-882966;

E-mail biarchiv@ nyx. uni-konstanz.de detergents, and other surfactants (Howard 1990) and is also used as a buffering agent. Little is known about the microbial degradation of this compound. Triethanolamine is converted, probably via triethanolamine $\mathrm{N}$-oxide, into diethanolamine and glycolate by a gram-negative rod (Williams and Callely 1982). The comparably high stability of the alkyl-nitrogen linkage causes considerable problems for anaerobic degradation of this compound. A similar problem exists with degradation of nitrilotriacetate (NTA), which is used as a chelating agent in detergents. In aerobic degradation by Pseudomonas species, NTA is converted by an NADH-dependent monooxygenase into an unstable aldimine hydrate that decomposes easily into iminodiacetate and glyoxylate (Cripps and Noble 1973). Degradation of NTA in the absence of molecular oxygen was reported for a nitrate-reducing bacterium (Egli et al. 1990). In this case, dehydrogenation followed by water addition leads to formation of iminodiacetate and glyoxylate; the dehydrogenase enzyme has been purified recently and couples with high-potential electron acceptors such as phenazine methosulfate (Jenal-Wanner and Egli 1993).

The present study shows that in the absence of molecular oxygen, the alkyl-nitrogen linkage of triethanolamine can be split through a corrinoid-dependent hydroxyl shift reaction, analogous to the cleavage of ether bonds in anaerobic polyethylene glycol degradation (Schramm and Schink 1991; Frings et al. 1992).

\section{Materials and methods}

Source of organisms

Strain LuTria 3 was isolated from anoxic digested sludge of the municipal sewage plant in Tübingen-Lustnau, Germany.

Media and growth conditions

Carbonate-buffered, sulfide-reduced mineral medium, prepared as previously described (Widdel and Pfennig 1981), contained 7-vitamin solution (Widdel and Pfennig 1981), selenite-tungstate solu- 
tion (Tschech and Pfennig 1984), and the trace element solution SL 10 (Widdel et al. 1983). The final $\mathrm{pH}$ of the medium was adjusted to 7.2-7.4. The growth temperature was $28^{\circ} \mathrm{C}-30^{\circ} \mathrm{C}$.

\section{Isolation and characterization}

Pure cultures were obtained using the agar shake culture method (Pfennig 1978). Purity was checked microscopically and by growth tests in medium containing $5 \mathrm{~m} M$ fumarate, $5 \mathrm{~m} M$ pyruvate, $0.05 \%$ yeast extract, and $5 \mathrm{mM}$ triethanolamine. Gram staining was carried out according to Bartholomew (1962). The DNA base composition was determined by high-pressure liquid chromatography (Tamaoka and Komagata 1984; Mesbah et al. 1989) after extraction of DNA according to Marmur (1961). The DNA of bacteriophage $\lambda$ was used as a reference. Substrate utilization was tested in $22-\mathrm{ml}$ screw-cap tubes. Substrates were added from neutralized and filter-sterilized stock solutions. Utilization of $\mathrm{H}_{2}$ was tested in $15-\mathrm{ml}$ Hungate tubes sealed with butyl rubber septa, with $10 \mathrm{ml}$ basal medium under an atmosphere of $80 \% \mathrm{H}_{2} / 20 \% \mathrm{CO}_{2}$. Optical densities were measured directly in a Bausch and Lomb Spectronic 20 photometer (Milton Roy, Rochester, N.Y., USA) in 22-ml screw-cap tubes. Cell dry matter was calculated from the turbidity at $420 \mathrm{~nm}$ using the conversion factor $0.1 \mathrm{OD}_{420}=15.4$ mg dry matter per liter, which was obtained by direct gravimetric determinations in 1-1 cultures grown with triethanolamine.

Preparation of cell-free extracts

Cells were harvested in the late log phase $\left(\mathrm{OD}_{420}=0.45\right)$ by centrifugation under anoxic conditions for $30 \mathrm{~min}$ at $4^{\circ} \mathrm{C}$ and $3000 \times$ $g$ in 125-ml infusions bottles (Müller \& Krempel, Bülach, Switzerland). The pellet was washed once with $50 \mathrm{mM}$ potassium phosphate buffer ( $\mathrm{pH} 7.0$; prereduced with $2.5 \mathrm{~m} M$ titanium citrate) and resuspended in the same buffer. Cell-free extracts were prepared by five runs through an $\mathrm{N}_{2}$-flushed French pressure cell at 138 $\mathrm{MPa}$ and centrifuged at $3000 \times g$ to remove cell debris.

\section{Enzyme assays}

All enzyme assays were carried out under strictly anoxic conditions in $\mathrm{N}_{2}$-gassed- and rubber-sealed cuvettes. Activities were measured photometrically in a Hitachi 100-40 spectrophotometer (Hitachi, Tokyo, Japan). Triethanolamine-degrading enzyme activity was determined as NADH-dependent reduction of acetaldehyde formed, at a wavelength of $340 \mathrm{~nm}$ (modified after Toraya and Fukui 1982). The reaction mixture contained $500 \mathrm{~m} M$ potassium phosphate buffer $(\mathrm{pH} 8.0$; prereduced with $2.5 \mathrm{~m} M$ titanium citrate), $0.2 \mathrm{~m} M \mathrm{NADH}, 10 \mathrm{U}$ alcohol dehydrogenase, and $50 \mathrm{mM}$ triethanolamine. Phosphotransacetylase and acetate kinase were measured by standard methods (Bergmeyer 1983). Acetaldehyde:acceptor oxidoreductase and pyruvate:acceptor oxidoreductase were determined with benzyl viologen as electron acceptor (modified after Odom and Peck 1981). Carbon monoxide dehydrogenase was assayed with benzyl viologen as electron acceptor (Diekert and Thauer 1978).

\section{Chemical analyses}

Acetate was determined by gas chromatography as previously described (Platen and Schink 1987). Formation of ammonia was analyzed according to Chaney and Marbach (1962). Protein was determined as described by Bradford (1976) using bovine serum albumin as a reference.

\section{Chemicals}

Chemicals were obtained from Boehringer, Mannheim, Germany; Fluka, Neu-Ulm, Germany; Merck, Darmstadt, Germany; and Sigma, Deisenhofen, Germany. All chemicals were of analytical quality. Gases were obtained from Messer Griesheim, Darmstadt, Germany, and from Sauerstoffwerk, Friedrichshafen, Germany.

\section{Results}

Enrichment cultures in minimal medium with $5 \mathrm{~m} M$ triethanolamine were inoculated with anaerobic digestor sludge. After five to six transfers, three strains of morphologically similar bacteria were isolated by two subsequent agar shake dilutions, and one of these, strain LuTria 3 , was characterized in detail.

\section{Morphology and cytology}

Cells of strain LuTria 3 were straight rods with rounded to slightly pointed ends, $1.0 \times 2.0-3.25 \mu \mathrm{m}$ in size (Fig. 1 ). They occurred singly, in pairs, or in short chains. Cells were motile in the early logarithmic growth phase. Spores were never detected, and the cells were gram-positive. The $\mathrm{G}+\mathrm{C}$ content of the DNA was $34.9 \pm 1.0 \mathrm{~mol} \%$.

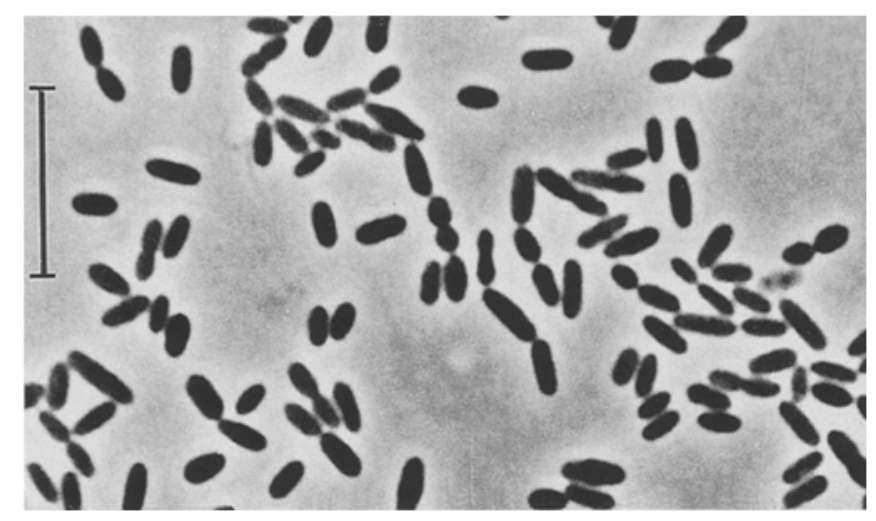

Fig. 1 Phase-contrast photomicrograph of strain LuTria 3. Bar equals $10 \mu \mathrm{m}$

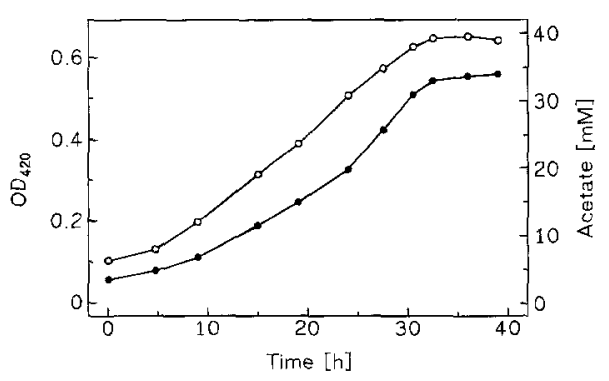

Fig. 2 Fermentation time course of strain LuTria 3 growing with $10 \mathrm{~m} M$ triethanolamine as substrate. $\mathrm{OD}_{420}$ : optical density at 420 nm wavelength. Symbols: $\bigcirc$ cell density; acetate 
Table 1 Stoichiometry of fermentation and growth yield of strain LuTria 3. Values given are means of two independent assays

\begin{tabular}{lc}
\hline Triethanolamine degraded & $500.0 \mu \mathrm{mol}$ \\
Acetate formed & $1701.0 \mu \mathrm{mol}$ \\
Ammonia formed & $467.0 \mu \mathrm{mol}$ \\
Ethanol formed & $26.2 \mu \mathrm{mol}$ \\
Cell dry mass formed $^{\mathrm{a}}$ & $4.9 \mathrm{mg}$ \\
Acetate assimilated $^{\mathrm{b}}$ & $101.0 \mu \mathrm{mol}$ \\
Ammonia assimilated & $47.6 \mu \mathrm{mol}$ \\
Carbon recovery & $98.2 \%$ \\
Electron recovery & $98.1 \%$ \\
Nitrogen recovery & $103.0 \%$ \\
Growth yield & $9.8 \mathrm{~g} \mathrm{~mol}^{-1}$ \\
\hline
\end{tabular}

a Calculated via cell density using an experimentally determined conversion factor $\left(0.1 \mathrm{OD}_{420}=15.4 \mathrm{mg}\right.$ dry cell matter $\left.\mathrm{I}^{-1}\right)$

${ }^{b}$ Calculated according to the formula:

$17 \mathrm{CH}_{3} \mathrm{COOH} \rightarrow 8<\mathrm{C}_{4} \mathrm{H}_{7} \mathrm{O}_{3}>+2 \mathrm{CO}_{2}+6 \mathrm{H}_{2} \mathrm{O}$

\section{Physiology}

Strain LuTria 3 grew only under strictly anoxic conditions in freshwater medium. $\mathrm{NaCl}$ concentrations were tolerated up to $5 \mathrm{~g} / \mathrm{l}$. Growth was not inhibited by phosphate up to $50 \mathrm{~m} M$. The $\mathrm{pH}$ range was $6.0-8.2$, with an optimum at $\mathrm{pH} 7.1-7.4$. The temperature range was $12^{\circ}$ to $37^{\circ}$ $\mathrm{C}$; optimal growth was found at $25^{\circ}$ to $30^{\circ} \mathrm{C}$ with a doubling time of $12 \mathrm{~h}$ (Fig. 2). Triethanolamine was fermented to acetate and ammonia according to the following equation:

$$
\begin{aligned}
& 4\left(\mathrm{HOCH}_{2} \mathrm{CH}_{2}\right)_{3} \mathrm{NH}^{+}+6 \mathrm{CO}_{2}+6 \mathrm{H}_{2} \mathrm{O} \rightarrow \\
& 15 \mathrm{CH}_{3} \mathrm{COO}^{-}+15 \mathrm{H}^{+}+4 \mathrm{NH}_{4}^{+}
\end{aligned}
$$

The stoichiometry of substrate utilization, product formation, and growth yield are presented in Table 1. Formate, 3,4,5-trimethoxybenzoate, 3,4,5-trimethoxycinnamate, 1,2propanediol, acetoin, glycerol, lactate, pyruvate, and ethanolamine, but no sugars, were utilized as growth substrates (Table 2). Neither inorganic electron acceptors (sulfate, thiosulfate, sulfur, nitrate) nor fumarate was reduced.

\section{Enzyme activities}

Enzymes were assayed in cell-free extracts of strain LuTria 3 grown with triethanolamine (Table 3). A triethanolaminedegrading enzyme activity forming acetaldehyde as reaction product was measured; optimal activity was found with a potassium phosphate buffer of high ionic strength $(500 \mathrm{~m} M)$. This reaction was stimulated 30 -fold by added adenosylcobalamin (coenzyme $\mathrm{B}_{12}, 10 \mu M$ ) and inhibited completely by cyanocobalamin (vitamin $\mathrm{B}_{12}, 10 \mu M$ ) or hydroxocobalamin $(10 \mu M)$. The triethanolamine-degrading enzyme activity measured with added coenzyme $B_{12}$ was tenfold higher than the physiological activity of cells growing exponentially with triethanolamine $(0.197 \mu \mathrm{mol}$ $\mathrm{min}^{-1} \mathrm{mg}$ protein). In cell-free extracts of the new isolate conversion of diethanolamine was also measured.
Table 2 Substrates tested for growth with strain LuTria 3; concentration of substrates added was $10 \mathrm{~m} M$, unless indicated otherwise (in parentheses)

\section{Substrates utilized:}

$\mathrm{H}_{2} / \mathrm{CO}_{2}(80 \% / 20 \%$ ), formate (20), 3,4,5-trimethoxybenzoate (5), 3,4,5-trimethoxycinnamate (5), 1,2-propanediol, acetoin, glycerol, lactate, pyruvate, ethanolamine, diethanolamine, triethanolamine

Substrates not utilized:

Methanol, ethanol, propanol, butanol, pentanol, ethylene glycol, 2,3-butanediol, fumarate, malate, glucose (5), fructose (5), arabinose (5), xylose (5), mannose (5), galactose (5), sucrose (5), maltose (5), lactose (5), ribose (5), choline (5), betaine, ethylamine (5), triethylamine (5), diethylene glycol, PEG 400 $(0.1 \%)$, methoxyethanol

Table 3 Enzymes measured in cell-free extracts of strain LuTria 3

\begin{tabular}{|c|c|c|}
\hline Enzyme & $\begin{array}{l}\text { EC } \\
\text { number }\end{array}$ & 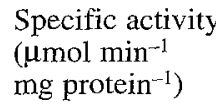 \\
\hline $\begin{array}{l}\text { Triethanolamine-degrading } \\
\text { enzyme }^{\mathrm{a}}\end{array}$ & - & 1.960 \\
\hline Ethanolamine ammonia-lyase & 4.3 .1 .7 & 0.086 \\
\hline $\begin{array}{l}\text { Acetaldehyde: acceptor oxido- } \\
\text { reductase }\end{array}$ & 1.2 .1 .10 & 2.440 \\
\hline Phosphate acetyltransferase & 2.3 .1 .8 & 7.410 \\
\hline Acetate kinase & 2.7 .2 .1 & 0.081 \\
\hline CO-dehydrogenase ${ }^{c}$ & 1.2 .99 .2 & 3.460 \\
\hline $\begin{array}{l}\text { Pyruvate: acceptor oxido- } \\
\text { reductase }\end{array}$ & 1.2 .7 .1 & 0.125 \\
\hline
\end{tabular}
grown with triethanolamine

a Coenzyme $\mathrm{B}_{12}$-dependent

b Benzyl viologen and coenzyme A-dependent

c With benzyl viologen as electron acceptor

Ethanolamine ammonia-lyase was detected at low activity ( $44 \%$ of the physiological activity) and was not influenced by various corrinoids. Acetaldehyde:acceptor oxidoreductase, phosphate acetyltransferase, and carbon monoxide dehydrogenase all were found at sufficient activities, whereas the acetate kinase activity measured accounted for only $40 \%$ of the physiological activity.

\section{Discussion}

\section{Physiology and biochemistry}

In the present study, fermentative degradation of triethanolamine is described for the first time. The new isolate, strain LuTria 3, fermented triethanolamine to acetate and ammonia. The key reaction in degradation of triethanolamine is cleavage of the comparably stable alkylnitrogen linkage. From our results obtained by enzyme assays with cell-free extracts of strain LuTria 3, we propose the pathway of anaerobic triethanolamine degradation depicted in Fig. 3. A triethanolamine-degrading enzyme ac- 


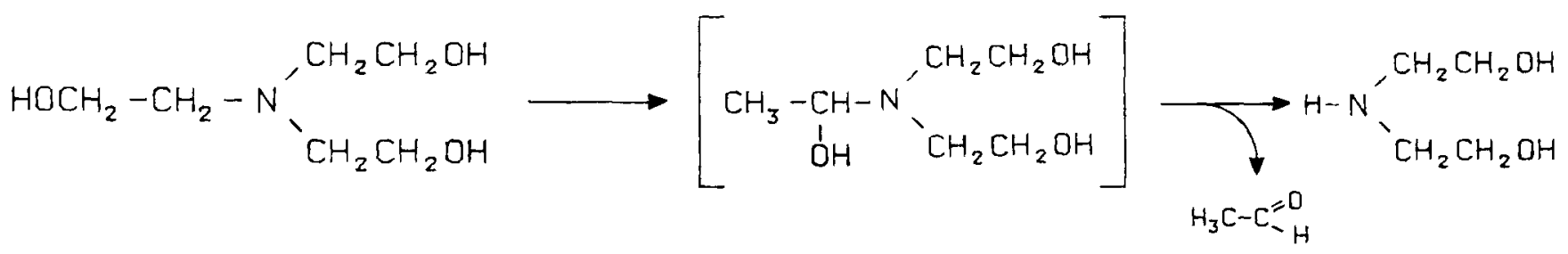<smiles>CC(=O)[C@H](C)CNCCOC(C)[C@H](C)NC(C)O</smiles>

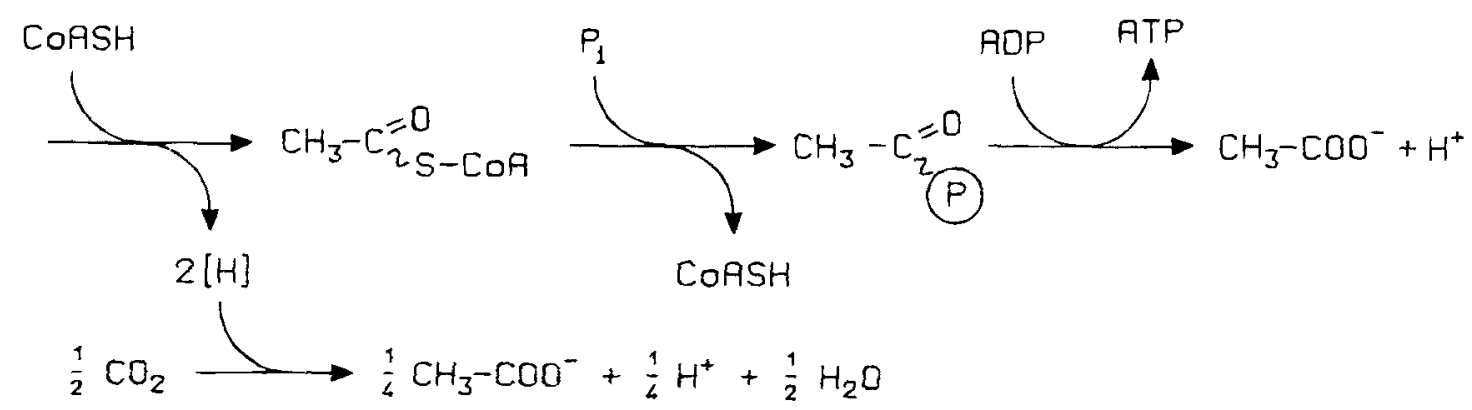

Fig. 3 Proposed pathway for anaerobic triethanolamine degradation by strain LuTria 3

tivity was detected that led to the formation of acetaldehyde as product and was stimulated 30 -fold by added coenzyme $B_{12}$ and inhibited by other corrinoids. This result indicates that in the first step, a terminal hydroxyl group of triethanolamine is shifted to the subterminal carbon atom, analogous to a coenzyme $\mathrm{B}_{12}$-dependent diol dehydratase reaction (Toraya and Fukui 1982). By this reaction, cleavage of the alkyl-nitrogen linkage is prepared because the hemiaminal thus formed is unstable and decomposes easily to acetaldehyde and diethanolamine. In the same way, diethanolamine is cleaved to ethanolamine and acetaldehyde. In cell-free extracts of strain LuTria 3, ethanolamine ammonia lyase activity forming acetaldehyde and ammonia was present, but was not influenced by various corrinoids. In contrast, the ethanolamine ammonia lyases of other bacteria, e.g., Clostridium sp., Escherichia coli, Klebsiella aerogenes, or Salmonella typhimurium, are coenzyme $\mathrm{B}_{12}$-dependent (Babior 1982). The ethanolamine cleavage by strain Lutria 3 is possibly dependent on other corrinoids, or corrinoids of this strain could be bound tightly to the enzyme and not be displaced by added cobalamines.

The acetaldehyde formed in triethanolamine degradation is oxidized to acetate by an acetaldehyde:acceptor oxidoreductase that reacts in the cell probably with a low potential electron acceptor such as ferredoxin, to form acetyl coenzyme A. Phosphate acetyltransferase and acetate kinase were measured in cell-free extracts of the new isolate as well. The reducing equivalents are utilized to reduce carbon dioxide to acetate through the carbon monoxide dehydrogenase pathway.

Our results demonstrate for the first time that the alkylnitrogen linkage of triethanolamine is cleaved by a reaction mechanism similar to that postulated for the cleavage of the ether bond in anaerobic polyethylene glycol degradation (Schramm and Schink 1991; Frings et al. 1992). In both cases, corrinoid-dependent shifting of a hydroxyl group forms an unstable intermediate (a hemiacetal or hemiaminal), which decomposes easily.

Other alkyl-nitrogen compounds, such as triethylamine or NTA, were not degraded in our experiments, either by strain LuTria 3 or by sulfide-reduced strictly anaerobic enrichment cultures. These observations indicate that a free terminal hydroxyl group is required to allow cleavage of the alkyl-nitrogen linkage through a hydroxyl shift reaction.

\section{Energetics}

Conversion of triethanolamine to acetaldehyde and ammonia is an exergonic reaction [calculation after Thauer et al. 1977 ; the $\Delta \mathrm{Gf}^{\circ}$ value for triethanolamine, $-315.6 \mathrm{~kJ} / \mathrm{mol}$, was calculated after the increment method ( $D^{\prime}$ Ans and Lax 1983)],

$\left(\mathrm{HOCH}_{2} \mathrm{CH}_{2}\right)_{3} \mathrm{NH}^{+} \rightarrow 3 \mathrm{CH}_{3} \mathrm{CHO}+\mathrm{NH}_{4}^{+}$

$\triangle \mathrm{G}^{0^{\circ}}=-77.3 \mathrm{~kJ} / \mathrm{mol}$ triethanolamine

The further reaction to acetate is an exergonic process as well:

$4 \mathrm{CH}_{3} \mathrm{CHO}+2 \mathrm{CO}_{2}+2 \mathrm{H}_{2} \mathrm{O} \rightarrow 5 \mathrm{CH}_{3} \mathrm{COO}^{-}+5 \mathrm{H}^{+}$

$\triangle \mathrm{G}^{0^{-}}=-55.9 \mathrm{~kJ} / \mathrm{mol}$ acetaldehyde 
It is unlikely that the free energy of triethanolamine conversion to acetaldehyde and ammonia is conserved by these bacteria; the corresponding polyethylene glycol cleavage reactions are also not exploited energetically (Schramm and Schink 1991; Frings et al. 1992). Fermentation of acetaldehyde to acetate includes a substrate level phosphorylation step, and further energy should be conserved in homoacetogenic acetate synthesis. Nonetheless, the cell yield obtained $(\leq 3.3 \mathrm{~g} / \mathrm{mol}$ acetaldehyde) is low, indicating that either the $Y_{\text {ATP }}$ value is unusually low with this bacterium (Stouthamer 1979) or that this fermentation involves energy-consuming steps such as reversed electron transport or electrogenic substrate/product transport processes.

\section{Taxonomy}

The new bacterium described in this communication, strain LuTria 3, was enriched and isolated with triethanolamine as sole source of energy and carbon. The new isolate was able to grow autotrophically with $\mathrm{H}_{2} / \mathrm{CO}_{2}$. Formate, 3,4,5-trimethoxybenzoate, 3,4,5-trimethoxycinnamate, 1,2-propanediol, acetoin, glycerol, lactate, pyruvate, and ethanolamine were fermented. Carbon monoxide dehydrogenase was found at high activity, and the $\mathrm{G}+\mathrm{C}$ content of the DNA was determined to be $34.9 \pm 1.0 \mathrm{~mol} \%$. These properties, together with the characteristic cell shape and motility, allow the assignment of strain LuTria 3 to the genus Acetobacterium (Schink and Bomar 1991). The new isolate differs from other species of the genus described so far by its capacity to grow with triethanolamine and its inability to utilize ethylene glycol or fructose. Strain LuTria 3 was deposited with the Deutsche Sammlung für Mikroorganismen $\mathrm{GmbH}$, Braunschweig, Germany, under DSM 8909.

Acknowledgements This study was supported by a grant from the Bundesministerium für Forschung und Technologie, Bonn, in a special program on biotechnology of coal.

\section{References}

Babior BM (1982) Ethanolamine ammonia-lyase. In: Dolphin D (ed) $\mathrm{B}_{12}$, vol 2. Wiley, New York, pp 264-287

Bartholomew JW (1962) Variables influencing results and the precise definition of steps in gram staining as a means of standardizing the results obtained. Stain Technol 37:139-155

Bergmeyer HU (1983) Methods of enzymatic analysis (Vols II-III). Verlag Chemie, Weinheim

Bradford MM (1976) A rapid and sensitive method for the quantitation of microgram quantities of protein utilizing the principle of protein-dye binding. Anal Biochem 72:248-254

Chaney AL, Marbach EP (1962) Modified reagents for the determination of urea and ammonia. Clin Chem 8:130-132

Cripps RE, Noble AS (1973) The metabolism of nitrilotriacetate by a pseudomonad. Biochem J 136:1059-1068
D'Ans J, Lax E (1983) Taschenbuch für Chemiker and Physiker, 4th edn. (Organische Verbindungen, vol 2) Springer, Berlin Heidelberg New York

Diekert G, Thauer RK (1978) Carbon monoxide oxidation by Clostridium thermoaceticum and Clostridium formicoaceticum. J Bacteriol 136:597-606

Egli T, Bally M, Uetz T (1990) Microbial degradation of chelating agents used in detergents with special reference to nitrilotriacetic acid (NTA). Biodegradation $1: 121-132$

Frings J, Schramm E, Schink B (1992) Enzymes involved in anaerobic polyethylene glycol degradation by Pelobacter venetianus and Bacteroides strain PG 1. Appl Environ Microbiol 58: 2164-2167

Howard PH (1990) Handbook of environmental fate and exposure data for organic chemicals, vol 2. Lewis, Michigan, pp 488 492

Jenal-Wanner U, Egli T (1993) Anaerobic degradation of nitrilotriacetate (NTA) in a denitrifying bacterium: purification and characterization of the NTA dehydrogenase-nitrate reductase enzyme complex. Appl Environ Microbiol 59:3350-3359

Marmur J (1961) A procedure for the isolation of deoxyribonucleic acid from micro-organisms. J Mol Biol 3: 208-218

Mesbah M, Premachandran U, Whitman W (1989) Precise measurement of the $\mathrm{G}+\mathrm{C}$ content of deoxyribonucleic acid by high performance liquid chromatography. Int I Syst Bacteriol 39:159-167

Odom JM, Peck HD (1981) Localization of dehydrogenases, reductases, and electron transfer components in the sulfate-reducing bacterium Desulfovibrio gigas. J Bacteriol 147:161-169

Pfennig N (1978) Rhodocyclus purpureus gen. nov, and sp. nov., a ring shaped, vitamin $\mathrm{B}_{12}$-requiring member of the family Rhodospirillaceae. Int J Syst Bacteriol 28:283-288

Platen H, Schink B (1987) Methanogenic degradation of acetone by an enrichment culture. Arch Microbiol 149:136-141

Schink B, Bomar M (1991) The genera Acetobacterium, Acetogenium, Acetoanaerobium, and Acetitomaculum. In: Balows A, Trüper HG, Dworkin M, Harder W, Schleifer KH (eds) The procaryotes, 2nd edn, vol 1. Springer, New York Berlin Heidelberg, pp 1925-1936

Schramm E, Schink B (1991) Ether-cleaving enzyme and diol dehydratase involved in anaerobic polyethylene glycol degradation by a new Acetobacterium sp. Biodegradation 2:71-79

Stouthamer AH (1979) The search for correlation between theoretical and experimental growth yields. Int Rev Biochem $21: 1-47$

Tamaoka J, Komagata K (1984) Determination of DNA base composition by reversed-phase high-performance liquid chromatography. FEMS Microbiol Lett $25: 125-128$

Thauer RK, Jungermann K, Decker K (1977) Energy conservation in chemotrophic anaerobic bacteria. Bacteriol Rev $41: 100-180$

Toraya T, Fukui $S$ (1982) Diol dehydrase. In: Dolphin D (ed) $B_{12}$, vol 2. Wiley, New York, pp 233-262

Tschech A, Pfennig N (1984) Growth yield increase linked to caffeate reduction in Acetobacterium woodii. Arch Microbiol 137. 163-167

Widdel F, Pfennig N (1981) Studies on dissimilatory sulfate-reducing bacteria that decompose fatty acids. I. Isolation of new sulfate-reducing bacteria enriched with acetate from saline environments. Description of Desulfobacter postgatei gen. nov. sp. nov. Arch Microbiol 129:395-400

Widdel F, Kohring GW, Mayer F (1983) Studies on dissimilatory sulfate-reducing bacteria that decompose fatty acids. III. Characterization of the filamentous gliding Desulfonema limicola gen. nov, sp. nov., and Desulfonema magnum sp. nov. Arch Microbiol 134 : 286-294

Williams GR, Callely AG (1982) The biodegradation of diethanolamine and triethanolamine by a yellow gram-negative rod. J Gen Microbiol 128: 1203-1209 